\title{
Exploration of Ideological and Political Theory Course Teaching in Sports Colleges Based on Mobile Internet
}

\author{
Wang Qingbao ${ }^{\text {a }}$, Lu Ming ${ }^{\text {b }}$, Wang Ke ${ }^{\mathrm{c}}$, Li Jiabao ${ }^{\mathrm{d}}$ \\ College of Physical Education, Baicheng Normal University, Baicheng 137000, China \\ awqb1105@163.com, bluming8012@126.com, 'wangke69222@163.com, dgarbo9024@sina.cn
}

Keywords: Mobile Internet; Sports Colleges; Ideological and Political Theory Course

\begin{abstract}
Information technology has become a form of science that people can not be divorced from, and it can be said that we are in the era of information coverage with mobile Internet as information media, which greatly improves the convenience we receive and disseminate information. With the help of information technology, the teaching efficiency of Ideological and political theory course in sports colleges can be improved, and the ideological and political theory course teaching in sports colleges based on the mobile Internet was explored in this paper.
\end{abstract}

\section{Introduction}

Compared to the sports teaching dynamic, teaching the ideological and political theory course is the main form of the theory of static full flavor. If you simply put the ideological and political theory course confined to the classroom, it is difficult to mobilize students learning interest. This is because the sports college students are accustomed to dynamic teaching, their concept is more advanced, accept love fresh knowledge. According to the characteristics of sports college students, ideological and political theory course both abstract and actual situation of strong theoretical, it is necessary for teachers to introduce mobile Internet technology in the sports colleges ideological and political theory course teaching, in order to improve the learning interest of the students, reduce the ideological and political theory teaching so as to improve the level of abstraction and the efficiency of teaching.

\section{The Connotation and Advantages of Mobile Internet}

In the information era, the mobile Internet is basically covering more than $90 \%$ of the urban and rural population. Only with a receiving terminal, can realize network information interoperability. The mobile phone as an example, the current smart mobile phone number in China has reached about 700 million, is the world of smart mobile phone with the largest number of countries. China's Internet technology also at the forefront of the world. The developed technology and convenient conditions of use, changing people's habits.

Add the mobile Internet based on the original mobile communication on the Internet is the Internet properties, support technology, to build a platform to build general business model and mobile communication technology. After the merger of the mobile Internet has incomparable superiority, has compact and lightweight and easy to carry, pay attention to the protection of user privacy, signal stability and network characteristics convenient connection.

\section{Characteristics of Students in Institutes of Physical Education}

The Basic Knowledge of Culture Is Weak, and the Abstract Rational Thinking Is Poor. The teaching mode of students in sports colleges and universities was used to be dynamic. They tend to be more physical and motor skills learning, generally for the basic cultural knowledge level is not high. They keep the resistance for the abstract conceptual content, failed to establish a rational structure of thinking and abstract, with a sense of self used to make decisions.

Self Disciplined Ability Is Poor, Self-Consciousness Is Stronger. The child accepted professional sports training, they only in the training ground and abide by the relevant court order 
system, but in learning and life are self-centered, slack, lack of self-discipline consciousness. In the classroom, they think their main energy is not in the knowledge to learn and master, but in sports skills and learning. So they treat negative classroom learning, sleeping in class often play mobile phone, chat, voice is not conducive to classroom learning. In life, very impulsive, often because some small and big hit hands, just because I think the motivation necessary to help friends out "and other non rational judgment.

They Have Very Strong Adaptability, Good at Self-Expression. The main task of students in physical exercise college is to study the sports, so they created a sensitive nerve response. They think faster, have stronger ability to improvise, can adapt a strange environment soon , and quickly into the environment. Compared with other students, the sports college students desire self-expression is stronger, they are more happy, good performance. This and their long-term expectations game, achieve excellent results in the game are closely related.

Have a Strong Sense of Collective Honor. Although the sports college students are self-centered, randomness is strong, hard to concentrate in class to seriously study the negative theory of scientific and cultural knowledge, but in relation to the class of honor games or other activities, they will naturally attach great importance to, and to honor the efforts of the class. Best. This is the sport itself contains the team consciousness, the collective ideas and a natural sense of honor in order to succeed.

\section{Analysis of the Current Situation of Ideological and Political Course in Physical Education Colleges}

Students' Attitudes Towards Ideological and Political Education in Physical Education Institutes. At present, sports colleges and universities ideological and political course mainly by Basic Principle of Marxism, Mao Zedong thought and the theoretical system of socialism with Chinese characteristics, Deng Xiao-ping Theory, Ideological and moral cultivation and legal basis. These courses is to help students establish a correct world outlook, values and outlook on life things, clear method of judgment, improve the students' ideological abstraction and generality. But most of the students of the ideological and political theory course is not interested, they think these courses with their majors even to learn, misfits, and passive acceptance. They think the purpose of passive learning political theory course is not active remould their world outlook, outlook on life and values, but only in learning itself, let the content without the application of any, should pay for the examination for learning They become the study of Ideological and political theory course. Only for the purpose of setting the wrong understanding of distorted school curriculum teaching goal, once the end of the examination, the knowledge will be left to the "window", to learn to lose the proper value.

The Preliminary Understanding of the Ideological and Political Theory Course By the Students of Sports Colleges and Universities in the Mobile Internet Way. Compared with the traditional classroom teaching mode, the sports college students generally think that the use of mobile Internet learning of Ideological and political theory courses more attractive, they will cause more concern and attention. Indeed, the mobile Internet has many features, for we learn to bring convenience, but also can improve the convenience of learning not only. Are students, even we ourselves will often use the mobile Internet to learn, so the mobile Internet application from political theory teaching has certain positive role in promoting, students can come up with mobile phone at any time, at any place to learn, have access to the Internet. The school can take full advantage of the Internet, the part of the content of Ideological and political theory course of the transfer to the Internet for students to learn, and to learn the contents reflected in the final exam questions such as teaching. Teachers can focus and difficult part of Ideological and political education in the use of micro lesson form recorded, uploaded to the school website, or point-to-point sent to their e-mail, can also be sent to the cloud disk, let the students rational use of time to download at any time, online learning. 


\section{Problems Needed Play Attention in Ideological and Political Theory Teaching in Sports Colleges based on Mobile Internet}

Resisting the Cyclical Impact of Western Ideology on the Mainstream Values of China. The mobile Internet is always in the open state, openness and inclusiveness is its inherent attribute, and it will give the opportunity of some western hostile forces have an ulterior motive due to the openness of the Internet, concept of value, and they published widely western concept of value on China's mobile Internet, the worship of money, carpe diem, conspiracy theory and idealism views that against ideology of China's mainstream values appear on the Internet cyclically, seriously disrupting the ideological work in our country. Theoretical knowledge of the sports college students was relatively weak, and the cyclical impact of western wrong ideas will make their belief shake step by step and have the wrong understanding in the world outlook and values. In this regard, the sports colleges should be vigilant and repeatedly stressed the mainstream value concept in our country in the ideological and Political Education courses by using the Internet.

Constantly Supplement the Knowledge and Content that Can Not Be Involved in Class Teaching. In traditional classroom teaching, some knowledge and contents in the classroom were very difficult to completely clear, because of the tight classroom teaching time and the heavy task, and a lot of content only in the superficial form, so it is easy to overlook some key and difficult teaching. In this regard, the mobile internet teaching should give the organic supplement to the knowledge and content that can not be involved or less involved in classroom teaching, making ideological and systematic teaching be systematization and integration. Ideological and political teaching content based on the mobile Internet need ensure to use the thinking of the Internet to deconstruct the teaching content, and internet can not be regarded as a simple tool and internet teaching still follow the traditional teaching mode, if you take the same way of teaching online and offline, that will let the students think that the school just make "boring" from one form into another, so that the Internet can not reach the effect of teaching. Therefore, online teaching must follow the thinking way of the Internet, using the Internet concept to solve the problem on the Internet. In addition, also note that the Internet ideological and political education is just a part of classroom teaching, and the teaching content cannot migrate to the Internet totally, this is because that the combination of education at the present stage and the technology of the Internet is still in the experimental stage, only after repeated demonstration and establishing the ideological and political teaching system of mature Internet, that just have overall migration conditions.

Teachers Should Take the Initiative to Assume more Responsibilities of the Internet "Lecturer". Sports colleges ideological and political teachers have been accustomed to the traditional classroom teaching mode, who accustomed to be as a main character in the classroom teaching of Ideological and political education, but when combined with the Internet, the teaching subject occurs fundamentally, students become the main body of teaching. In the internet teaching, ideological and political teachers should always think of the students' acceptance of each knowledge point, understand their hobbies and characteristics, and then make effective teaching plans. Because the internet Ideological and political teachers only unilateral teaching of teachers, students are not in the same time, so the teaching difficulty is increased significantly, only the initiative to innovation in the way of teaching and the content, the real from the students' habits and interest point of view, that make the students who get rid of the pressure in classroom teaching have a good impression to the teachers on the mobile phone screen and take the initiative to accept the ideological and political teaching content. Teachers should take more responsibility of the Internet "lecturer" in the Internet teaching, and have more skill and ability, such as the ability of information collection and dissemination, the ability to mobilize the enthusiasm of the students of speech and eloquence, ability to adjust atmosphere, gestures performance ability and so on.

Students Should Establish the Sense of Honesty and Consciously Complete the Network Teaching. The biggest problem of the Internet Ideological and political teaching is whether students can actively complete the learning tasks on the Internet. The Internet teaching is different from classroom teaching, and in the classroom teachers can get feedback from students at any time, know the students' master degree of knowledge, also can urge students to complete classroom exercises 
content, but on the Internet that can only rely on conscious. For the students of sports colleges, it is difficult to consciously learn the ideological and political theory knowledge, which requires positive guidance and encouragement of teachers under the guidance of the Internet. The school should help students to establish the integrity awareness through positive guidance, make them conscientiously complete learning tasks on the Internet, such as Investigate online learning content regularly, combine content of online learning with final examination results, increase online learning content in the final examination and so on, to guide students to consciously learn the Internet Ideological and political course.

\section{The Way to Implement Ideological and Political Theory Course Teaching based on Mobile Internet}

The contents of mobile internet teaching need be showed through the mobile phone, iPad, notebook computer and other mobile terminal equipment at last, so the premise of teaching based on the mobile Internet is that students must master the use of the mobile terminal equipment expertly and know the function of these devices is not only entertainment, but also learning.

Teachers and Students Cooperate Actively and are Initiative to Explore the Teaching of Internet Ideological and Political Theory Course. The task of exploration and development of ideological and political theory course in sports colleges do not belong to teachers entirely, but also students. Teachers and students should give suggestions actively, and promote ideological and political theory course teaching of the colleges to gradually mature. The teacher cannot be autocratic and completely ignore students' opinions and suggestions, only by their own "teaching experience" persist in wilfully and arbitrarily; Students can not ignore the internet ideological and political theory teaching and think that it has nothing to do with themselves. It can not achieve the desired effect of the teaching that if only one-way research and exploration, and ultimately only make ideological and political theory teaching one-sided.

Construct the Internet Ideological and Political Education Learning Platform Actively. Sports colleges should actively invest in the construction of internet ideological and political education learning platform, and make students be convenient to learn online. The internet ideological and political learning platform not only covers some video content of classroom teaching, but also includes exercise, unit testing, interaction, feedback and other multiple connection projects, and provide convenient services for students' Ideological and Political learning in all aspects.

Strengthen Ideological and Political Teachers' Network Information Technology Training. Sports Colleges ideological and political teachers' professional knowledge is generally high, but for the knowledge of the Internet may not be mastered, so colleges should organize regular training of network information technology for ideological and political teachers, and let teachers establish the internet thinking, understand the operating rules of the internet, and grasp the method of internet teaching mode, so as to completely use knowledge in the internet teaching.

Skillfully Use the Online and Offline Teaching Methods to Enrich the Teaching Content. For sports students, ideological and political learning is full of abstract and boring, it is difficult to mobilize their enthusiasm in learning, therefore, in Ideological and political classroom teaching, we may as well take teaching methods of online and offline combination. Ahead of the classroom teaching, the teachers carefully record a micro class, and put forward several key problems in this class that will be learned in the micro class, the style of micro class should be humorous, interesting, full of readability, the key is to let students remember this problem in the micro class; then, in the classroom teaching, the teacher ask students to study and have a group discussion according to the problem, and then ask each group to answer the questions; and then the teacher let each group to evaluate the different answers of other groups, record the answers and evaluation content on the blackboard, and guide the students to fully discuss; finally teacher evaluate the answer of each group, and get the correct answer at last. The online and offline learning model fully respects the subjectivity of students in learning, and students participate in the whole process of teaching, form an effective interaction with teachers, and ultimately learn the relevant experience knowledge. 


\section{Conclusion}

The internet is changing our life, and also affect the sports college ideological and political theory course. Only if taking the initiative to change themselves, establishing the Internet thinking, and actively bringing internet to ideological and political theory course, we can meet the needs of the times and meet the students' needs, promoting the ideological and political theory the course to be a new height.

\section{References}

[1] GE Cui-bai. College students hospital ethical problems and responses to the thinking[J]. Journal of Nanjing Institute of Physical Education(Natural Science),2011,10(4):102-104. .

[2] ZHANG Guo-qi, Sun Lu. On the internet thinking of ideological and political education development[J]. Heilongjiang Researches on Higher Education,2015,(6):107-110.

[3] LIN Xiu-fen. Research on internet plus ideological and political education in Colleges[J].Extensive Collection of The Party History,2016,(8):55-56

[4] CAI Chun-di, LI Hai-jian. Approach to explore the effect of ideological and political education of students in sports colleges under the new media environment[J]. The Party Building and Ideological Education in Schools,2013,(3):56-57.

[5] WANG Jiao. Elementary introduction of the innovation of ideological and political education methods for college students in physical education institutes[J]. intellectual guide,2015,(23):14. 